\title{
ANALISIS STUDI KELAYAKAN PENGEMBANGAN USAHA CANOPY DAN ATAP BAJA RINGAN PADA CV. BAJA JAYA LAS MUARA BULIAN
}

\author{
Muryati, Feny Juhanti \\ Sekolah Tinggi Ilmu Ekonomi Graha Karya Muara Bulian, Jambi, Indonesia
}

\begin{abstract}
The objective of this study was to determine how much investment is needed for development of Canopy and Light Steel Roof business in Lembah Kuamang village, Pelepat Ilir sub-district, Muara Bungo District. And then, was to assess all the aspect in business development of Canopy and Light Steel Roof and to assess the business development feasibility by analyzing Investment Criteria. The investment needed was Rp. 564,210,000,- which consists their own capital was Rp. 394,210,000,bank loan was Rp. 170,000,000,- through bank credit at BRI Bank with 9\% interest rate. Aspects were assess, include legal aspects, management aspects and Human Resources, market and marketing aspects, technical and technological aspects, financial and economic aspects. From the evaluation of business development feasibility of Canopy and Light Steel Roof in Lembah Kuamang village, Pelepat Ilir sub-district, Muara Bungo District, this business was feasible to be developed. Based on calculations using the investment criteria analysis on CV. Baja Jaya Las in Lembah Kuamang village, the result was: NPV: Rp. 223,944,943,452,- was greater than 1 means that this business is feasible to be developed, IRR $27.07 \%$ was greater than SOCC means that this business is feasible to be developed, NET B/C 1.56 was greater than 1 means this business is feasible to be developed, GROSS $B / C 1.04$ was greater than 1 means that this business is feasible to be developed, PR 2.08 was greater than 1 means that this business is feasible to be developed, BEP for 3 Years 9 Months 20 Days was greater than the economic age means that this business is feasible to be developed.
\end{abstract}

Keywords: Legal aspects, management aspects and Human Resources, market and marketing aspects, technical and technological aspects, financial and economic aspects, and Investment Criteria (NPV, IRR, NET B/C, GROSS B/C, PR, and BEP)

\section{PENDAHULUAN}

UKM adalah sebuah istilah yang mengacu kejenis usaha kecil yang memiliki kekayaan bersih Rp. 200.000.000,- tidak termasuk tanah dan bangunan tempat usaha. Dan usaha yang berdiri sendiri. Menurut keputusan Presiden RI.No.99 tahun 1998 pengertian usaha kecil adalah “ Kegiatan ekonomi rakyat yang berskala kecil dengan bidang usaha yang secara mayoritas merupakan kegiatan usaha kecil dan perlu dilindungi untuk mencegah dari persaingan usaha yang tidak sehat".

Belakangan ini, perkembangan perekonomian terutama di bidang UKM kian terasa meningkat, bahkan moderenisasi terjadi di berbagai aspek kehidupan. Sehingga beragam UKM yang dilakukan untuk memenuhi kebutuhan kian beragam pula. Dengan beragamnya UKM yang dilakukan tersebut, maka kita harus mampu bersaing untuk memenuhi kebutuhan dan bertahan hidup. Untuk itu kita harus berinvestasi atau menanamkan modal dalam bentuk UKM agar menjamin kehidupan kita dimasa yang akan datang.

Investasi ini biasanya disesuaikan dengan tujuan perusahaan dan bentuk badan usahanya. Salah satu tujuan usaha didirikan pada umumnya untuk memperoleh laba (profit), meningkatkan penjualan, meningkatkan nilai saham, meningkatkan kesejahteraan pemegang saham.

Tujuan lain adalah bersifat social, artinya jenis usaha ini didirikan untuk membantu masyarakat dalam penyediaan berbagai sarana dan prasarana yang dibutuhkan masyarakat, seperti pendidikan, rumah sakit, panti-panti sosial, rumah yatim piatu dan usaha sosial lainnya.

Disamping itu ada juga perusahaan yang didirikan dengan tujuan keduaduanya, artinya disamping ingin memperoleh laba juga memberikan pelayanan sosial. Namun prakteknya usaha 
sosial juga memperoleh keuntungan sehingga mampu untuk membiayai usahanya sendiri, dan tidak tergantung pada donatur.

Setiap pengusaha akan selalu berusaha agar usaha yang dijalankan dapat memberikan manfaat atau keuntungan, karena motif usaha pada umumnya adalah profit motif. Tidak ada pengusaha yang ingin menanggung resiko kerugian. Oleh karena itu, sebelum mendirikan atau melaksanakan usaha, pengusaha perlu melakukan analisis studi kelayakan bisnis untuk mengetahui layak tidaknya rencana usaha tersebut dilaksanakan. Peranan studi kelayakan bisnis menjadi sangat penting untuk mengadakan penilaian terhadap gagasan usaha yang mempunyai sumber dana dari lembaga tersebut. Dengan adanya studi kelayakan bisnis dalam berbagai kegiatan usaha dapat diketahui sejauh mana gagasan usaha yang akan dilaksanakan mampu menutupi segala kewajibankewajibannya serta prospeknya di masa yang akan datang.

Berdasarkan pada hasil penilaian ini lah para pihak perbankan menyetujui atau tidak terhadap permintaan kredit bukan hanya bergantung pada studi kelayakan yang akan diajukan, tetapi juga tergantung pada jaminan kredit, koneksi atau hubungan antar pengusaha dengan pihak perbankan disamping bonafid tidaknya pengusaha tersebut, namun demikian peranan studi kelayakan usaha mempunyai andil yang cukup besar dalam mendapatkan kredit.

Dalam menyusun studi kelayakan bisnis banyak hal yang berhubungan dalam perhitungan bunga dan nilai uang, seperti beban bunga, tingkat bunga, nilai uang, nilai pinjaman beserta cicilan ( kredit ) serta perhitungan penyusutan terhadap asset yang digunakan. Faktor - faktor yang perlu dinilai dalam menyusun studi kelayakan bisnis adalah menyangkut dengan beberapa aspek antara lain aspek hukum, aspek pasar dan pemasaran, aspek teknis dan teknologi, aspek manajemen dan organisasi, aspek teknis dan teknologi, aspek ekonomi dan sosial, aspek lingkungan dan aspek keuangan. Studi kelayakan bisnis merupakan pedoman kerja, baik dalam penanaman investasi, pengeluaran biaya, cara produksi, cara pelaksanaan pemasaran dan hasil produksi dan cara dalam menentukan jumlah tenaga kerja serta jumlah pemimpin yang diperlukan. Berdasarkan latar belakang inilah maka kami belajar untuk membuat suatu usaha dengan mengutamakan peranan aspek studi kelayakan bisnis tersebut.

Perumusan masalah yang diangkat adalah bagaimana analisis studi kelayakan investasi pengembangan usaha CV. BAJA JAYA LAS Muara Bulian, Dan kemampuan investasinya dalam memberikan keuntungan terhadap jumlah modal yang ditanam? Studi ini akan menitik beratkan pada penentuan layaknya investasi.

Adapun tujuan penelitian yang ingin dicapai sebagai berikut: Untuk mengetahui dan menganalisis kelayakan investasi pengembangan usaha CV. BAJA JAYA LAS Muara Bulian

\section{Kerangka Pemikiran}

Studi Kelayakan usaha pada hakekatnya merupakan suatu kegiatan yang wajib dilakukan, karena studi kelayakan usaha ini sebagai salah satu langkah untuk meminimalisir kegagalan dalam menjalankan usaha, karena salah satu tujuan studi kelayakan usaha ini untuk menghindari kemungkinan resiko yang muncul selama usaha dijalankan.

Ada beberapa aspek yang perlu dilakukan studi kelayakan usaha untuk menentukan kelayakan usaha. Masing masing aspek tidak berdiri sendiri, akan tetapi saling berkaitan. Urutan penilaian aspek mana yang akan didahulukan tergantung pada kesiapan penilai dan kelengkapan data yang ada. Adapun aspek yang akan dinilai dalam melakukan studi kelayakan usaha secara umum meliputi : aspek hukum, aspek pasar dan pemasaran, aspek manajemen dan organisasi, aspek teknis dan teknologi, aspek ekonomi dan 
sosial, aspek lingkungan, aspek keuangan yang secara keseluruhan akan dinilai kelayakannya. Dari keterangan diatas diharapkan setiap resiko yang muncul dapat diminimalkan dan pencapaian tujuan dapat dicapai secara optimal. Secara singkat dapat diilustrasikan dalam Gambar 1 berikut:

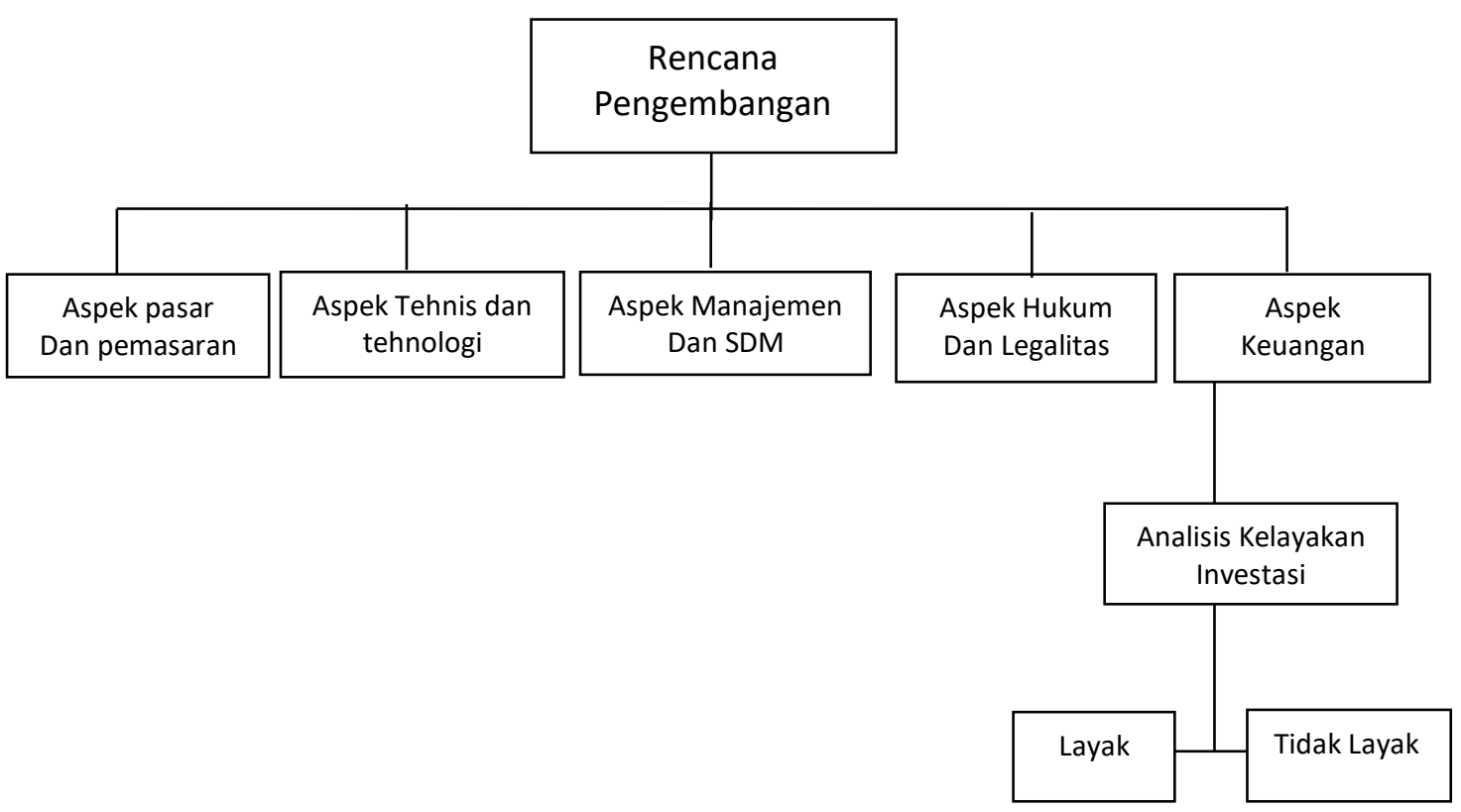

Gambar 1. Kerangka Pemikiran

\section{Landasan Teori}

Menurut Ibrahim dalam Gumelar (2016), studi kelayakan bisnis adalah kegiatan untuk menilai sejauh mana manfaat yang dapat diperoleh dalam melaksanakan suatu kegiatan usaha atau proyek.

Sedangkan menurut Kadariah, Kahlien dan Clive (1999), proyek sebagai suatu keseluruhan aktivitas yang menggunakan sumber-sumber untuk mendapatkan kemanfaatan (benefit), atau suatu aktivitas di mana dikeluarkan uang dengan harapan untuk mendapatkan hasil (return) di waktu yang akan datang dan dapat direncanakan, dibiayai dan dilaksanakan sebagai satu unit

Tujuan dilakukannya analisis bisnis (Gray dan Larson, 2007) adalah (1) Untuk mengetahui tingkat keuntungan yang dapat dicapai melalui investasi dalam suatu proyek; (2) Menghindari pemborosan sumber-sumber daya, yaitu menghindari pelaksanaan kegiatan yang tidak menguntungkan; (3) Mengadakan penilaian terhadap peluang investasi yang ada sehingga dapat memilih alternatif kegiatan yang paling menguntungkan;

Menentukan prioritas investasi. Rangkuti dalam Syarif (2011) menjelaskan kemampuan analisis pemasaran sangat penting untuk keberhasilan perusahaan. Jika suatu perusahaan dapat menjual lebih banyak produk yang sama, dengan kualitas yang sama, dengan harga yang lebih mahal, atau dapat mengembangkan produk baru yang lebih berhasil, perusahaan tersebut relatif telah berhasil menggunakan kemampuan analisis pemasarannya

Kotler dalam Syarif (2011) Potensi pasar dapat dianalisis melalui:a)Pendekatan permintaan menekankan tentang kebutuhan manusia yang sampai sekarang belum sepenuhnya terpenuhi atau kemungkinan sudah terpenuhi namun kurang memuaskan.b)Pendekatan penawaran berawal dari kemampuan dalam membuat suatu produk/barang, memberikan pelayanan jasa atau gabungan dari keduanya.c)Membatasi Jangkauan Pasar, mengukur secara rasional seberapa luas jangkauan usaha Anda dan tentukan siapa target pasar Anda. 
Strategi pemasaran adalah penggabungan oleh wirausahawan terhadap penelitian pasar yang bermakna dengan suatu rencana untuk mengembangkan daya saing dalam pasar sasaran tertentu untuk menciptakan bauran pemasaran yang berhasil (Thomas \& Norman, 2002). Umar dalam Syarif (2011) manajemen operasional adalah suatu fungsi atau kegiatan manajemen yang meliputi perencanaan, organisasi, staffing, koordinasi, pengarahan dan pengawasan terhadap operasi

perusahaan. Ada tiga masalah pokok yang dihadapi perusahaan yaitu masalah penentuan posisi perusahaan, masalah desain dan masalah operasional. Kelancaran suatu usaha berhubungan erat dengan teknis yang digunakan oleh perusahaan tersebut. Aspek teknis mencakup penggunaan komponen input dan Output, baik berupa barang maupun jasa (Pramudya dalam Roeflina ,2007).

Aspek finansial merupakan suatu gambaran yang bertujuan untuk menilai kelayakan suatu usaha untuk dijalankan atau tidak dijalankan dengan melihat dari beberapa indikator yaitu: Net Present Value (NPV), Net Benefit/Cost Rasio, Internal Rate of Return (IRR), Payback Periode (PP), sensitivitas.

Aspek-aspek dalam studi kelayakan bisnis:

1. Aspek pasar dan pemasaran

Dalam melakukan penelitian pasar dan pemasaran menurut Subagyo

Kegiatan dilakukan sebelum kegiatan Bisnis dimulai

(2008:650) perlu diadakan penelitian terhadap beberapa hal yang perlu diperhatikan yaitu permintaan, penawaran, proyeksi permintaan dan penawaran, proyeksi penjualan, produk (barang/jasa), segmentasi pasar strategi dan implementasi pemasaran.

2. Aspek Tehnis Produksi dan Tehnologi Tujuan aspek teknis ialah:

a. Agar perusahaan dapat menentukan lokasi yang tepat,baik untuk lokasi pabrik, gudang, cabang maupun kantor pusat .

b. Agar perusahaan bisa menentukan layout yang sesuai dengan proses produksi yang dipilih sehingga dapat memberikan efisiensi.

c. Agar perusahaan bisa menentukan tehnologi yang paling tepat dalam menjalankan produksinya.

d. Agar perusahaan dapat menentukan metode persediaan yang paling baik untuk dijalankan sesuai dengan bidang usahanya.

e. Agar perusahaan bisa menentukan kualitas tenaga kerja yang dibutuhkan sekarang dan dimasa yang akan datang (Kasmir dan Jakfar, 2009:146).

3. Aspek Manajemen dan Sumber Daya Manusia

Aspek Manajemen dan sumber daya manusia terdiri dari tiga kegiatan dan hubungan ketiga aspek tersebut dapat diilustrasikan dalam gambar berikut:

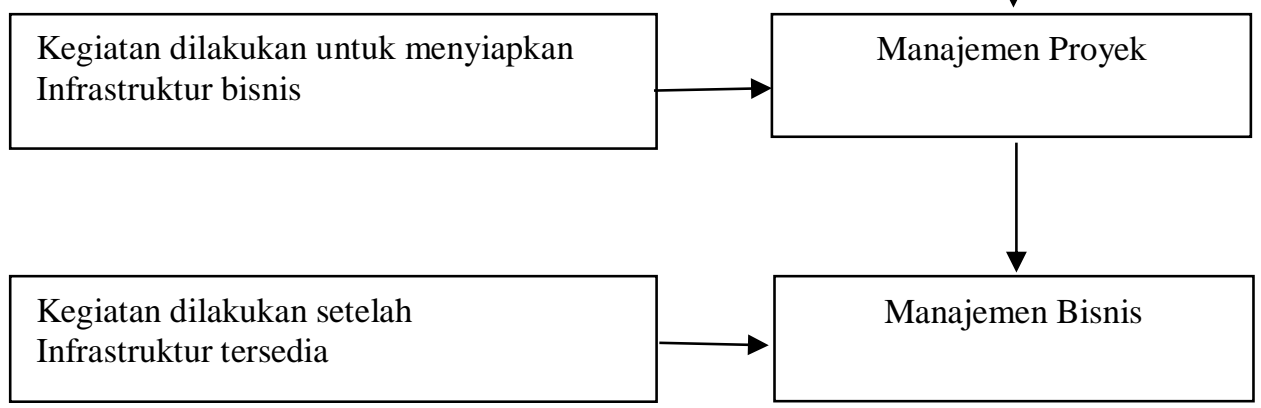

Gambar 2. Hubungan Aspek Manajemen 
4. Aspek Hukum dan Legalitas

Tujuan dari aspek hukum adalah untuk meneliti keabsahan, kesempurnaan dan keaslian dari dokumen-dokumen yang dimiliki. Suatu usaha dikatakan legal jika telah mendapatkan izin usaha dari pemerintah daerah setempat melalui instansi atau lembaga atau departemen atau dinas terkait.

Kegiatan usaha dimana pun selalu memerlukan dokumen penunjang usaha beserta izin-izin yang diperlukan sebelum menjalankan usahanya.

5. Aspek Keuangan dan Ekonomi

Aspek keuangan dan ekonomi terdapat enam kriteria yang bisa digunakan untuk menentukan kelayakan suatu usaha atau investasi yaitu Payback period (PP), Net Present Value (NPV), Average Rate Of Return (ARR), Internal Rate Of Return (IRR), Profitability Index (PI) (Kasmir dan Jakfar:2007:97)

\section{Pengertian Investasi}

Secara umum investasi adalah penanaman modal ( baik modal tetap maupun modal tidak tetap) yang digunakan dalam proses produksi untuk memperoleh keuntungan suatu perusahaan. Menurut Halim (2005:4) investasi pada hakekatnya merupakan penempatan sejumlah dana pada saat ini dengan harapan untuk memperoleh keuntungan di masa mendatang.

\section{Pengertian Aliran Kas (Cash Flow)}

Setiap usulan pengeluaran modal selalu mengandung dua macam aliran yaitu aliran kas keluar netto ( net outflow of cash) yaitu yang diperlukan untuk investasi baru dan aliran kas masuk netto tahunan (net annual inflow of cash) yaitu sebagai hasil dari investasi baru tersebut, sering disebut " net cash procceds" atau "procceds"

\section{METODOLOGI PENELITIAN}

Objek penelitian ini adalah CV. Baja Jaya Las Muara Bulian merupakan usaha ha yang bergerak dalam sektor bidang kontruksi atap Canopy dan Atap Baja ringan.

\section{Jenis Dan Tehnik Pengumpulan Data}

Adapun jenis data dalam penelitian ini ialah data kuantitatif berupa data investasi untuk asset tetap seperti tanah, gedung, dan peralatan lainnya, data biaya tetap dan biaya variabel yang berkaitan serta biaya lainnya dan data kualitatif berupa keterangan, informasi, penjelasan, pendapat dan tanggapan dari pemilik. Sedangkan jenis data menurut sumbernya adalah data primer yang diperoleh secara langsung dari obyek penelitian dan data sekunder yang diperoleh melalui studi pustaka mengenai investasi.

\section{Metoda Analisa Data}

1. Analisis Aspek-aspek Dalam Studi Kelayakan

a. Aspek Pasar dan Pemasaran membahas mengenai segmentasi dan target pasar, jumlah permintaan dan penawaran terhadap produk, kualitas dan spesifikasi produk, metoda penetapan harga dan promosi.

b. Aspek Teknis dan Tehnologi membahas mengenai deskripsi produk, penentuan lokasi dan lay out fasilitas.

c. Aspek Manajemen dan Sumber Daya Manusia membahas mengenai struktur organisasi, job discription, sistem kompensasi, program pengembangan karyawan serta sistem informasi manajemen (SIM).

d. Aspek Hukum dan Legalitas, membahas mengenai badan hukum organisasi dan jenis-jenis perizinan yang diperlukan.

e. Aspek Keuangan dan Ekonomi membahas mengenai penyusunan modal kerja dan modal investasi.

2. Metoda Depresiasi atau Penyusutan

Dalam menghitung penyusutan dengan menggunakan metoda garis lurus (straight line methode) 
$P=\frac{B-S}{N}$

$\mathrm{P}=$ Jumlah penyusutan per tahun

$\mathrm{B}=$ Harga beli asset

$\mathrm{S}=$ Nilai Sisa

$\mathrm{N}=$ Umur ekonomis asset
3. Alat Analisa Kelayakan Investasi

a. Net Present Value (NPV)

Net Present Value merupakan net benefit yang telah didiscount dengan menggunakan social opportunity cost of capital sebagai discount factor

$$
\mathrm{NPV}=\frac{\text { kas bersih } 1}{(1+r)}+\frac{\text { kas bersih } 2}{(1+r)^{2}}+\cdots+\frac{\text { kas bersih } \mathrm{N}}{(1+r)^{\mathrm{N}}}-\text { investasi }
$$

Dapat dianalisa bahwa :

Jika NPV > 0 Usulan usaha diterima (Positif)

Jika NPV < 0 Usulan usaha di tolak (Negatif)

Jika NPV $=0$ Nilai perusahaan tetap dan perlu pertimbangan lagi

b. Internal Rate Of Return (IRR)

IRR adalah suatu tingkat discount rata yang menghasilkan NPV $=0$ (nol), jika IRR > SOCC maka proyek dikatakan layak, jika IRR = SOCC berarti proyek pada BEP, dan jika IRR < SOCC maka proyek tidak layak dijalankan.

$$
\mathrm{IRR}=i_{1}+\left(\frac{N P V 1}{N P V 1+N P V 2}\right)\left(i_{1}-i_{2}\right)
$$

Dimana :

$i_{1}=$ Tingkat discount rata yang menghasilkan NPV1

$i_{2}=$ Tingkat discount rata yang menghasilkan NPV2

c. Gross Benefit Cost Ratio (Gross B/C) Gross B/C adalah perbandingan antara benefit kotor yang telah didiscount dengan cost secara keseluruhan yang telah didiscount.

$\operatorname{Gross} B / C=\frac{\sum_{i=1}^{n} \mathrm{~B}(1+\mathrm{r})^{-} \mathrm{n}}{\sum_{i=1}^{n} \mathrm{C}(1+\mathrm{r})^{-} \mathrm{n}}$

Jika Gross B/C > 1 berarti usaha layak dijalankan

Jika Gross B/C $<1$ berarti usaha tidak layak dijalankan

d. Net Benefit Cost Ratio (NET B/C)
Net $\mathrm{B} / \mathrm{C}$ adalah perbandingan antara net benefit yang telah didiscount positif (+) dengan net benefit yang telah didiscount negative

Net $B / C=\frac{\sum_{i=1}^{n} \mathrm{NB}^{1}(+)}{\sum_{i=1}^{n} \mathrm{NC}^{1}(-)}$

Jika Net B/C > 1 berarti usaha layak dikerjakan

Jika Net $\mathrm{B} / \mathrm{C}<1$ berarti usaha tidak layak dikerjakan

e. Break event Point (BEP)

BEP adalah titik pulang pokok dimana TR-TC. Terjadinya BEP tergantung pada lama arus penerimaan sebuah usaha dapat menutupi segala biaya operasi dan pemeliharaan serta biaya modal lainnya. Selama perusahaan masih berada dibawah BEP, selam itu perusahaan masih menderita kerugian, semakin lama perusahaan mencapai BEP, semakin besar saldo rugi.

$\mathrm{BEP}=\mathrm{T}-p_{-1}+\frac{\sum T C 1-\sum \text { Bicp-1 }}{B p}$

Dimana :

BEP : Break Event Point

T- $p_{-1}$ : Tahun sebelum terdapat BEP

Tc1 : jumlah total cos yang sudah didiskon

Bicp - 1: jumlah benefit yang telah didiskon sebelum BEP

$B p \quad$ : jumlah benefit pada BEP 


\section{HASIL DAN PEMBAHASAN Aspek Pasar dan Pemasaran}

Aspek pasar dan pemasaran untuk menilai apakah perusahaan yang akan melakukan investasi ditinjau dari segi pasar dan pemasaran yang diinginkan atau tidak.

Usaha Canopy dan Atap Baja Ringan Pada CV. Baja Jaya Las Muara Bulian ini bisa membuka cabang atau ekspansi di daerah Kabupaten Muara Bungo Tepatnya di desa Lembah Kuamang Kecamatan Pelepat Ilir Kabupaten Muara Bungo, dikarnakan bisa mampu memenuhi konsumen yang ada. Jumlah penduduk berdomisisli pada desa Lembah Kuamang lebih kurang sendiri terdiri dari 5 kampung, $28 \mathrm{RT}$, dengan total kepala keluarga 1.067 jiwa, serta total pendududk berjumlah 3.329 jiwa yang mana terdiri dari 1.731 jiwa laki-laki, dan 1.598 jiwa perempuan.

Di daerah ini juga perkembangan jumlah penduduknya pesat dan daya beli terhadap Unit-unit Canopy dan Atap Baja Ringan masih melonjak tinggi karna para penduduk yang brau mengenal tentang manfaat dari Canopy, serta di permudah dalam membangun atap dengan menggunakan Rangka Atap Baja Ringan,karna bnayaknya manfaat dari bahan baku besi itu sendiri. Di daerah tersebut juga merupakan jalan lintas dengan tingkat kelancaran yang baik. Sehingga mempermudah pemilik usaha untuk memsasarkan, atau memasangkan produknya di daerah tersebut. Didaerah Lembah Kuamang Kecamatan Pelepat Ilir Kabupaten Muara Bungo ini dinilai memiliki peluang sangat besar dikarenakan didaerah tersebut belum adanya pesaing dengan jenis usaha yang serupa.

Jika dilihat dari segi pesaing $\mathrm{CV}$. Baja Jaya Las mempunyai peluang yang sangat besar dikarenakan belum adanya pesaing dengan jenis usaha yang sama pada CV. Baja Jaya Las, serta kualitas produk yang baik, Artinya CV. Baja Jaya Las mempunyai peluang dalam pengembangan usahanya, maka secara Aspek Pasar dan Pemasaran usaha ini layak untuk dikembangkan.

\section{Aspek Tehnis Produksi dan Tehnologi}

1. Pemilihan Lokasi Usaha

Pemilihan Lokasi usaha ini karena tempat sangat strategis. dengan alamat yang terletak di desa Lembah Kuamang Kecamatan Pelepat Ilir Kabupaten Muara Bungo. Lokasi ini berada di jalan lintas sumatra dan mempunyai jumlah penduduk yang padat, dekat dengan pusat kota, akses jalan lancar dan pesaing yang masih minim.

2. Pemilihan Teknologi

Pengembangan usaha Canopy dan Atap Baja Ringan ini telah menggunaka teknologi terbaru, berupa mesin-mesin yang sudah lebih canggih, lebih cepat, dan lebih terperinci dalam memotong besi, dan mengecat, namun tetap masih memakai tenaga manusia dalam pengendaliannya.

Sedangkan untuk Administrasi, atau pembukuan sudah lebih moderen dengan menggunakan leptop, dan transaksi jauh lebih mudah. Berdasarkan penilaian dari aspek produksi dan tehnologi, usaha ini masuk dalam ketegori layak untuk dijalankan.

\section{Aspek Manajemen dan Sumber Daya Manusia}

1. Manejemen Organisasi

Dalam aspek manajemen dan sumber daya manusia (SDM) ini lebih menekan pada produktifitas dan kinerja dari CV. Baja Jaya Las Cabang Desa Lembah Kuamang dan dengan adanya struktur organisasi yang ada akan memudahkan dalam pembagian dan pelaksanaaan tugas kerja yang ada dan sesuai kemampuan yang dimiliki..

Dalam urusan manajemen ini dilakukan langsung oleh pimpinan atau pihak usaha selaku orang yang sudah berpengalaman sebagai pimpinan suatu organisasi maupun dalam menjalankan usahanya, sumber daya manusia yang ada pada CV. Baja Jaya Las Cabang Desa Lembah Kuamang Kecamatan Pelepat Ilir Kabupaten Muara Bungo ini juga dicari orang yang sebagai pekerja 
keras, bertanggung jawab, jujur, serta memiliki kemampuan mengendarai kendaraan roda empat (mobil), dan kendaraan roda dua (motor) sehingga dapat terpenuhinya sumber daya manusia yang ada.

2. Kebutuhan Tenaga Kerja

Dalam menjalankan usaha ini, dibutuhan 7 ( tujuh ) orang tenaga kerja yang ditempatkan sesuai dengan kebutuhan dan kriteria perusahaan. Kebutuhan terhadap tenaga kerja dapat terjadi perubahan yang dikarenakan perkembangan, kondisi dan keadaan lapangan.

3. Tingkat Balas Jasa

Usaha CV Baja Jaya Las Cabang Desa Lembah Kuamang menerapkan pembayaran Gaji perbulan. Jadi dari penilaian Kriteria Aspek Manajemen dan Aspek Organisasi, Usaha ini layak dijalankan.

\section{Aspek Hukum dan Legalitas}

Jenis Badan Hukum Usaha

Untuk menganalisa pelaksana bisnis, tentunya hal ini akan menyangkut pada badan usaha dan individu-individu yang terlibat, usaha ini merupakan usaha perseorangan. Dipilihnya jenis usaha perseorangan ini sangatlah sederhana dan tidak memerlukan pernyataan khusus, sebagaimana bentuk badan hukum lainnya. Usaha Canopy dan Atap Baja Ringan ini telah mendapatkan izin dari RT dan kelurahan setempat untuk membuka perluasan kabupaten Muara Bungo, tepatnya di desa lembah kuamang kecamatan pelepat ilir ini usaha Canopy dan Atap Baja Ringan ini belum memiliki SITU (Surat Izin Tempat Usaha) dan SIUP (Surat Izin Usaha Perdagangan). Tetapi dalam waktu dekat akan segera diurus perizinannya Artinya usaha ini berdasarkan penilaian Aspek Hukum layak dijalankan.

\section{Aspek Keuangan dan ekonomi}

1. Aspek Keuangan
Pada usaha penjualan Canopy dan Atap Baja Ringan ini pemilik CV. Baja Jaya Las di Desa Lembah Kuamang telah menghitung investasi awal yang harus dikeluarkan dan juga modal yang dibuthkan. Pemilik juga melakukan pinjaman modal kepada pihak perbankan yang akan dikembalikan dalam waktu yang ditentukan.

Selain itu pemilik juga telah melakukan perhitungan untuk pengembalian investasi sehingga dapat dinilai apakah usaha itu sudah sesuai dengan yang diharapkan atau belum. Sehinga pemilik dapat menggunakan modal yang sedikit tetapi mendapatkan untung yang cukup.

Pada pengembangan usaha ini analisis kelayakan finansial terdiri dari rencana kebutuhkan fisik, rencana anggaran biaya, biaya operasional, modal dan penerimaan dan analisis kriteria investasi.

2. Aspek Ekonomi

Dampak dari perkembanagn Usaha Canopy dan Atap Baja Ringan pada CV. Baja Jaya Las ini secara ekonomi meliputi :

a. Peningkatan pendapatan keluarga, dengan adanya pengembangan usaha Canopy dan Atap Baja Ringan ini akan memberikan peningkatan kepada masyarakat, terutama mereka yang menjadi tenaga kerja pada usaha CV. Baja Jaya Las di Desa Lembah KuamangKecamatan Pelepat Ilir Kabupaten Muara Bungo.

b. Dampak bagi pemerintah, dapat membantu pemerintah dalam peningkatan ekonomi, yaitu mengurangi pengangguran pada saat ini.

Jika dilihat dari Aspek Ekonomi CV. Baja Jaya Las ini sudah dinyatakan layak untuk dijalankan karena pemilik usaha telah memperhitungkan semua kebutuhan, dan dampak dari perkembangan usahanya.

Perhitungan Kreteria Investasi 
Rekapitulasi Biaya Tetap dan Biaya Jaya Las Desa Lembah Kuamang Variabel Pengembangan usaha CV Baja

Tabel 1. Rekapitulasi Biaya Tetap dan Biaya Tidak Tetap Pengembangan Usaha CV. Baja Jaya Las Desa Lembah Kuamang

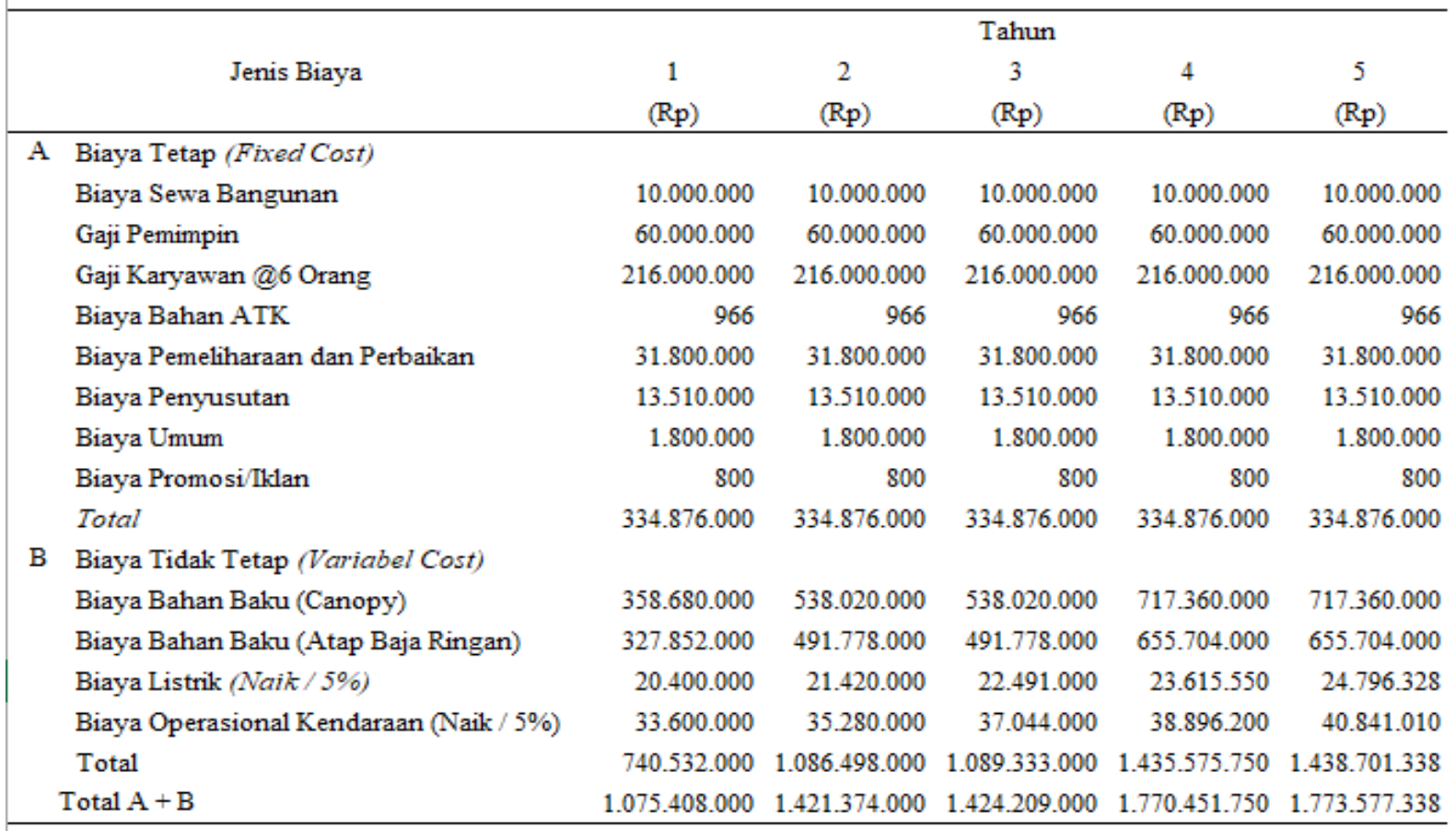

Sumber:Data diolah (2018)

Tabel 2. Perhitungan Net Persent Value (NPV) Pada Pengembangan Usaha CV. Baja Jaya Las Desa Lembah Kuamang

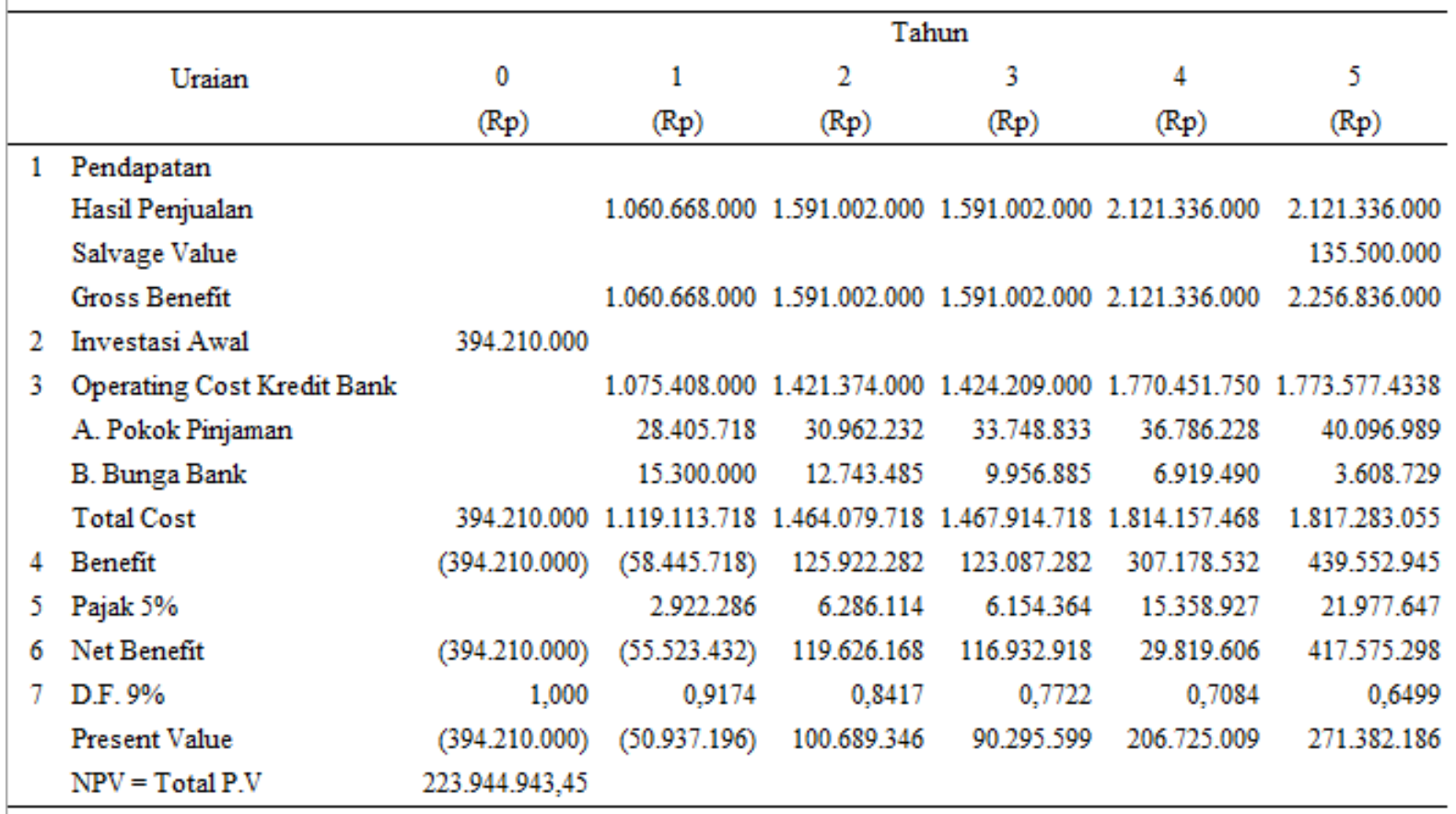

Sumber : Data Diolah (2018) 
Perhitungan Net Present Value

NPV $=$ Total PV Aliran Kas Bersih - Total PV Investasi

$\mathrm{NPV}=\mathbf{6 6 9 . 0 9 2 . 1 4 0}-\mathbf{4 4 5 . 1 4 7 . 1 9 6}$

$=223.944 .943$

Nilai NPV bernilai positif dengan nilai Rp. 223.944.943,- lebih besar dari nol. Ini berarti dari penilaian NPV Usaha pengembangan usaha canopy dan atap baja ringan desa lembah kuamang layak untuk dijalankan.

\section{Perhitungan Internal Rate Of Return (IRR)}

Metode ini digunakan untuk mengukur berapa tingkat pengembalian intern yang diperoleh dari suatu investasi. Berikut ini tabel 4.3 menunjukkan hasil perhitungan IRR dan PV kedua dengan DF sebesar $30 \%$ :

Tabel 3 Persiapan Perhitungan IRR dan Net B/C Pada Pengembangan Usaha CV. Baja Jaya Las Desa

\begin{tabular}{crrrrr} 
Tahun & $\begin{array}{c}\text { Net Benefit } \\
(\mathbf{R p})\end{array}$ & D.F 9\% & $\begin{array}{c}\text { Present Value } \\
(\mathbf{R p})\end{array}$ & D.F 30\% & \multicolumn{1}{c}{$\begin{array}{c}\text { Present Value } \\
(\mathbf{R p})\end{array}$} \\
\hline 0 & $(394.210 .000)$ & 1,000 & $(394.210 .000,000)$ & 1,000 & $(394.947 .000,000)$ \\
1 & 55.532 .432 & 0,9174 & 50.937 .196 & 0,7692 & 42.708 .623 .739 \\
2 & 119.626 .168 & 0,8417 & 100.689 .346 & 0,5917 & 70.782 .803 .725 \\
3 & 116.932 .918 & 0,7722 & 90.295 .599 & 0,4552 & 53.227 .864 .365 \\
4 & 291.819 .606 & 0,7084 & 206.725 .009 & 0,3501 & 102.166 .043 .956 \\
5 & 417.575 .298 & 0,6499 & 271.382 .186 & 0,2693 & 112.453 .027 .637 \\
& & NPV $\mathbf{1}$ & $\mathbf{2 2 3 . 9 4 4 . 9 4 3 , 4 5 2}$ & $\mathbf{N P V} \mathbf{2}$ & $\mathbf{( 9 8 . 2 8 8 . 8 8 4 . 0 5 6 )}$ \\
\hline
\end{tabular}

Sumber : Data diolah (2018)

$$
\begin{aligned}
& I R R=0,09+\left[\frac{223.944 .943 .425}{322.233 .827 .508}\right] \times(0,21) \\
& I R R=0,09+(0,694976518 \times 0,21) \\
& I R R=0,09+(0,14594506) \\
& I R R=0,23594506 \\
& I R R=23,59 \%
\end{aligned}
$$

Nilai IRR yang diperoleh adalah sebesar 23,59\% lebih besar dari bunga pinjaman sebesar 9\%, maka dari perhitungan IRR usaha pengembangan ini layak dijalankan.

\section{Perhitungan Net B/C}

Net $B / C=\frac{618.154 .943 .452}{394.210 .000,000}$

Net $\mathrm{B} / \mathrm{C}=1,56$

Berdasarkan pada hasil perhitungan kriteria investasi pada CV. Baja Jaya Las Desa Lembah Kuamang diatas, didapatkan bahwa nilai Net B/C sebesar 1,56 lebih besar dari 1, maka usaha ini Layak untuk dikembangkan.

\section{Perhitungan Gross B/C}

\begin{abstract}
Gross B/C $=\frac{6.510 .247 .090}{6.253 .767 .640}$
Gross B/C $=1,041011983$

Gross $\mathrm{B} / \mathrm{C}=1,04$

Dilihat dari perhitungan Gross Benefit Cost Ratio (Gross B/C) yang dibandingkan antara benefit kotor yang telah di discount dengan cost secara keseluruhan yang telah di discount adalah sebesar 1,04. Maka CV. Baja Jaya Las Desa Lembah Kuamang layak untuk dikembangkan karena Nilai Gross B/C lebih besar dari $1(1,04>1)$.
\end{abstract}

\section{Perhitungan PR}

$\begin{aligned} \mathrm{PR} & =\frac{6.510 .247 .090-5.689 .559 .916}{394.210 .000} \\ \mathrm{PR} & =\frac{820.687 .174}{394.210 .000} \\ \mathrm{PR} & =2,081852753 \\ \mathrm{PR} & =2,08\end{aligned}$

Berdasarkan pada hasil perhitungan Profability Ratio (PR) diatas maka CV. Baja Jaya Desa Lembah Kuamang dikatakan layak, karena Nilai Profability Ratio (PR) lebih besar dari 1. Dengan Nilai 
PR sebesar 2,08 lebih besar dari 1 (2,08 > $1)$.

\section{Perhitungan BEP}

$$
\begin{aligned}
& \mathrm{BEP}=3+\frac{6.253 .767 .676-5.043 .529 .373}{1.502 .754 .422} \\
& \mathrm{BEP}=3+\frac{1.210 .238 .302}{1.502 .754 .422} \\
& B E P=3+0,805346692 \\
& B E P=3 \text { tahun } 9 \text { bulan } 20 \text { hari } \\
& \text { Dapat dilihat dari hasil perhitungan }
\end{aligned}
$$

Break Event Point (BEP) pada CV. Baja Jaya Las di Desa Lembah Kuamang, memberikan gambaran titik pulang pokok dalam waktu 3 Tahun 9 Bulan 20 Hari, dapat diartikan bahwa usaha pengembangan ini layak untuk dijalankan karena BEP dibawah umur ekonomis ( 5 tahun)..

\section{SIMPULAN}

1. Investasi yang dibutuhkan untuk pengembangan usaha Canopy dan Atap Baja Ringan sebesar Rp. 564.210.000,yang terdiri dari modal sendiri sebesar Rp. 214.210.000,- dan melalui kredit perbankan di bank BRI sebesar Rp. 170.000.000,- .

2. Dari keseluruhan aspek yang telah diteliti, yaitu aspek hukum . aspek manajemen dan SDM, aspek pasar pemasaran, aspek teknik dan teknologi, aspek ekonomi, aspek lingkungan, dan aspek keuangan dari rencana pengembangan usaha Canopy dan Atap Baja Ringan ini telah memenuhi syarat dan menunjukan bahwa usaha pengembangan ini layak untuk dijalankan.

3. Dari perhitungan Kriteria Investasi sebagai berikut:

a. $\mathrm{NPV}=$ Rp. 223.944.943.452,Artinya Nilai NPV Positif, maka layak untuk dijalankan

b. IRR $=23,59 \%$ Nilai IRR lebih besar dari SOCC, Artinya layak untuk dijalankan

c. Net $\mathrm{B} / \mathrm{C}=1,56$ Nilai Net B/C lebih besar dari 1, Artinya usaha layak untuk dijalankan. d. Gross $\mathrm{B} / \mathrm{C}=1,04$ Nilai Gross $\mathrm{B} / \mathrm{C}$ lebih besar dari 1, layak untuk dijalankan.

e. $\mathrm{PR}=2,08$ Nilai PR lebih besar dari 1 , Artinya usaha layak untuk dijalankan.

f. BEP diperoleh hasil dibawah umur ekonomis artinya usaha ini layak dijalankan.

\section{DAFTAR PUSTAKA}

Agus, Indriyo.2005.Porfitabilitas pada Perusahaan Maufaktur Go Publik. Jakarta:Salemba Empat

Hasibuan, Malayu S. P. 2005. Manajemen Sumber Daya Manusia. Jakarta. PT Bumi Aksara.

Halim , 2003. Pengertian Investasi. Jakarta : Saleba Empat.Rizki,

Husein, Umar. 2010. Studi Kelayakan Bisnis. Yogyakarta ; Erlangga

Ibrahim, Yacob. 2009.Studi Kelayakan Bisnis. Jakarta ; Rineka Cipta

Ifnul Mubarok, Juliana. 2012 Kamus Istilah Ekonomi. Bandung : Yrama Widya.

Kasmir dan Jakfar. 2012. Studi Kelayakan Bisnis. Jakarta:Kencana

Kotler, Philip. 2005. Manajemen Pemasaran, Jilid 2, Edisi 11. Indeks, Jakarta. 